\title{
ADDITIONAL NEW GENERA AND SPECIES OF SOUTH AMERICAN THYNNINE WASPS (HYMENOPTERA:TIPHIIDAE) ${ }^{*}$
}

\author{
By LYNN S. KIMSEY \\ Department of Entomology, \\ University of California, Davis, CA 95616
}

\section{INTRODUCTION}

It is depressing to think that a group of large wasps such as the tiphiid subfamily Thynninae contains so many undescribed genera and species. Some of these new taxa are described in Kimsey and Genise (1991). The following genera are described separately herein because representative specimens are in the material I have accumulated from the northern Andes and southern Brazil, and are not in Jorge Genise's collection.

Specimens used in this study were borrowed from the following collections and individuals: Bohart Museum of Entomology, University of California, DAVIS, U.S.A. (R. O. Schuster, S. L. Heydon); C. Porter private collection, Gainesville, Florida; Canadian National Insect Collection, Agriculture Canada, OTTAWA, Ontario (L. Masner); Florida State Collection of Arthropods, GAINESVILLE, U.S.A. (L. A. Stange); Museu de Zoologia, Universidad de São Paulo, SÃo PAULO, Brazil (C. R. F. Brandao); Museum of Comparative Zoology, Harvard University, CAMBRIDGE, Massachusetts, U.S.A. (J. M. Carpenter, S. R. Shaw); U. S. Museum of Natural History, Washington, D. C., U.S.A. (A.S. Menke); Zoologisk Museum, Copenhagen, Denmark (O. Lomholdt); Zweite Zoologische Abteilung, Naturhistorisches Museum, Wien (Vienna), Austria (M. Fischer). An asterisk (*) following a species entry indicates that the primary type(s) were studied. Type repositories are indicated by city names in capital letters.

\footnotetext{
${ }^{*}$ Manuscript received by the editor February 9, 1991.
} 
Atopothynnus Kimsey, new genus

(Figs. 2, 7, 14)

Generotype: Atopothynnus unidens Kimsey.

Diagnosis.

Male: body length 11-16 mm; clypeus projecting apicomedially into a small narrow lobe, often slightly lobate apicolaterally (fig. 2); maxillary palpus $1.5 \times$ as long as stipes, apical palpal segments considerably longer than second and third; galea and lacinea short and weakly sclerotized; mandible apically bidentate or tridentate, if bidentate then strongly dilated submedially (fig. 2); tergum VII apically subtruncate with later carinae in dorsal view; sternum VIII apically rounded and ligulate or slightly constricted submedially; genital capsule (fig. 14): gonocoxa short and broad, convex and strongly projecting dorsally; gonostylus broad basally and either truncate or tapering apically; volsella apparently consisting of a single slender digitate lobe or bilobate structure; aedeagus basally linear with large rounded dorsomedial lobe and occasionally a small lobe before the apical loop; color black, yellow, and sometimes with orange.

Female: body length $8-10 \mathrm{~mm}$; mandible slender and edentate; pronotum subquadrate posteriorly, shallowly convex to anterior collar; tergum I with posterior transverse sulcus; tergum II with three transverse carinae; tergum $\mathrm{V}$ deeply emarginate posteromedially; tergum VI largely hidden by $\mathrm{V}$ except for narrow projecting medial lobe (fig. 7); S-VI subcylindrical with flat posterior surface horse hoof-shaped (fig. 7).

Etymology: Atopo-strange (Greek), thynnus-a commonly used word root for this subfamily (masculine).

Included species: Atopothynnus unidens Kimsey, Elaphroptera mimula (Turner) 1910.

Distribution. These wasps are only known from southern Brazil (Paraná).

Discussion. The odd configuration of the male clypeus is one of the more distinctive features of this genus. Other diagnostic characters are the greatly reduced female gastral tergum VI, and shape of the volsella. Atopothynnus appears to be most closely related to Zeena and Mesothynnus based on the presence of a slender apical lobe on the volsella in all three. 
Atopothynnus unidens Kimsey, new species

Diagnosis.

Holotype male: body length $11 \mathrm{~mm}$; forewing length $9 \mathrm{~mm}$; clypeus apicolaterally shallowly concave, medially shallowly emarginate and lateral corners rounded (fig. 2); mandible slender with small subsidiary and short apical tooth (fig. 2); flagellomere I $2 \times$ as long as broad, flagellomere II $2.3 \times$ as long as broad; frontal lobes over antennal sockets separated by a broad medial notch; pronotum laterally rough-looking with shallow nearly contiguous punctures; scutellum and propodeum also rough-looking with shallow punctures nearly 1 puncture diameter apart; genital capsule (fig. 12): gonostylus broad apically with dorsal angle broadly rounded and ventral angle sharp and toothlike, ventral margin angulate medially; aedeagus with two closely positioned, apically angulate lobes projecting ventrally at base of apical loop. Body black, with yellow markings on: ventral half of clypeus, mandibles medially, inner eye margin, frontal lobes, between ocelli, genal eye margin, narrow broken band across back of head, transverse line across pronotum, large and small lateral pronotal spots, scutum in two small medial spots and lateral line, mesopleural U-shaped subalar spot and small precoxal one, scutellar medial and lateral spots, metanotal lateral and medial spots, propodeal prespiracular spot and comma-shaped sublateral one, coxal and femoral stripes, abdominal segment I small basal spots, segments I and II transverse bands, and segments III-V lateral spots; tibiae and tarsi reddish brown; wings amber-tinted; pubescence pale golden.

Female: body length 8-9 $\mathrm{mm}$; mandible edentate and slender; frons with punctures 2-4 puncture diameters apart; subantennal distance to clypeal apex $2 \times$ malar space; pronotal disk subquadrate, convex medially and slightly depressed anteromedially, strongly declivous anteriorly to collar, collar narrower than disk, surface shagreened, punctures 1-2 PD apart medially; propleura flat ventrally, making the "neck" region appear elongate; forecoxae basal half of anterior surface sharply depressed; thoracic dorsum convex in profile; propodeum with discrete dorsal surface, broadly rounded to posterior face, posterior face strongly saddled; thoracic and abdominal integument shagreened; tergum VI posterior surface coarsely and irregularly punctate, apically with sharply carinate lateral lobe adjacent to long tuft of setae, with large 
triangular medial projection (fig. 7); sternum VI with posterior plate ovoid, with dorsomedial emargination (fig. 7). Body dark brown.

Paratype males vary slightly in color, some tending to have a more reddish abdomen, and range from $11-13 \mathrm{~mm}$ in length.

Holotype male: BRAZIL: Paraná, Colombo, 7 August 1974, H. R. Pimento (DAVIS). Paratypes: 1 male: Paraná, Curitiba, 29 September 1938, Claretiano (CAMBRIDGE); 2 males and 2 females: 9 June 1937, P. Pereire (são PAULO).

Discussion. Diagnostic features discussed for the genus will serve to separate this species from others with a similar appearance. The odd unilobate male clypeus may in fact be a specific character of little value in identifying the genus.

\section{Merithynnus Kimsey, new genus}

(Figs. 1, 3, 6, 9-11, 13)

Generotype: Merithynnus pecki Kimsey.

Diagnosis.

Male: body length 15-17 mm; clypeus apicomedially elongate, apical truncation apically shallowly emarginate between lateral toothlike angles (figs 1,3); maxillary palpus about twice as long as stipes, distal palpal segments longer than second and third, galea and lacinea short and weakly sclerotized; mandible bidentate, sometimes with small subbasal tooth on inner margin (figs. 1, 3); tergum VII apically truncate or somewhat rounded with lateral carinae in dorsal view; sternum VIII with lateral ridge terminating before apical platform, appearing notched submedially, apical platform ovoid and horse hoof-like; genital capsule (fig. 13): gonocoxa somewhat elongate dorsally, simple or slightly bilobate apically, gonostylus relatively broad in profile, ventral margin angulate with subapical notch or indentation; cuspis appressed against aedeagus, with short broadly rounded free apical lobe; aedeagal shaft short with large ventral lobe(s) before apical loop. Body color black and yellow.

Female: body length $8-10 \mathrm{~mm}$; tergum VI coarsely punctured dorsally, with four apicolateral lobes, and apicomedially convex or toothlike, and discrete tuft of setae over submedial pair of lobes 
(figs 6,9 ); sternum VI apical plate broadly ovoid or forming a half circle (figs. 6, 9).

Etymology: Meri-Merida, Venezuela; thynnus-commonly used ending in Thynninae (masculine).

Included species: Elaphroptera bogotana Turner 1910, Merithynnus osorioi Kimsey, Merithynnus pecki Kimsey, Elaphroptera turbulenta Turner 1910.

Distribution. All of these species are from the states of Merida and Yaracuy in Venezuela, and Valle Prov., Colombia, in the northeastern cordillera of the Andes.

Discussion. Generic relationships are unclear for Merithynnus. Superficially it resembles Zeena Kimsey, and Atopothynnus but the male clypeus, genitalia and female terminalia are distinctly different from these genera. The ventral aedeagal lobe indicates a relationship with Chrysothynnus, Dolichothynnus, Spilothynnus, Upa, Ammodromus, Brethynnus and Telephoromyia. However, the female terminalia is not rostrum-like, which suggests that Merithynnus is not closely related to Dolichothynnus, Spilothynnus and Upa.

\section{Merithynnus pecki Kimsey, new species}

Holotype male: body length $15 \mathrm{~mm}$; forewing length $13 \mathrm{~mm}$; clypeus apicolaterally shallowly concave, medially shallowly emarginate and lateral corners rounded (fig. 1); mandible slender with small subsidiary and short apical tooth (fig. 1); flagellomere I $2.5 \times$ as long as broad, flagellomere II $3 \times$ as long as broad; frontal lobes over antennal sockets separated by a broad medial notch; pronotum laterally rough-looking with shallow nearly contiguous punctures; scutellum and propodeum also rough-looking with shallow punctures nearly 1 puncture diameter apart; genital capsule (similar to fig. 13): gonostylus broad apically with dorsal angle broadly rounded and ventral angle sharp and toothlike, ventral margin angulate medially; aedeagus with 2 closely positioned, apically angulate lobes projecting ventrally at base of apical loop. Body black, with yellow markings on: ventral half of clypeus, mandibles medially, inner eye margin, frontal lobes, between ocelli, genal eye margin, narrow broken band across back of head, transverse line across pronotum, a large and small lateral pronotal 
spots, scutal small medial spots and lateral line, mesopleural Ushaped subalar spot and small precoxal one, scutellar medial and lateral spots, metanotal lateral and medial spots, propodeal prespiracular spot and comma-shaped sublateral one, coxal and femoral stripes, abdominal segment I small basal spots, segments I and II transverse bands, and segments III-V lateral spots; tibiae and tarsi reddish brown; wings amber-tinted; pubescence pale golden.

Female: body length $8-9 \mathrm{~mm}$; mandible edentate and slender; frons with punctures $2-4$ puncture diameters apart; subantennal distance to clypeal apex $2 \times$ malar space; thorax (fig. 11): pronotal disk subquadrate, convex medially and slightly depressed anteromedially, strongly declivous anteriorly to collar, collar narrower than disk, surface shagreened, punctures 1-2 PD apart medially; propleura flat ventrally, making the "neck" region appear elongate; forecoxal basal half of anterior surface sharp depressed; thoracic dorsum convex in profile; propodeum with discrete dorsal surface, broadly rounded to posterior face, posterior face strongly saddled; thoracic and abdominal integument shagreened; tergum VI posterior surface coarsely and irregularly punctate, apically with sharply carinate lateral lobe adjacent to long tuft of setae, with large triangular medial projection (fig. 10); sternum VI with posterior plate ovoid, with dorsomedial emargination (fig. 10). Body dark brown.

Paratype males vary slightly in the size of the yellow markings, and the body length ranges form 11 to $17 \mathrm{~mm}$.

Holotype male: venezuela: Merida, El Valle, $15 \mathrm{~km}$ e Merida, 2400 m, 24 June-July 1989, malaise trap, cloud forest (S. and J. Peck, ottawa). Paratypes: 48 males and 4 females (DAvis, otTAWA, CAMBRidge, BUENOS AIRES); 35 males and 3 females, same data as type; 11 males and 1 female: Merida, Tabay Mucuy, S. Truchicola, 19 June-24 July 1989, $230 \mathrm{~m}$, malaise trap (S. and J. Peck); 3 males: Merida, 20 km se Azulita, ULA Biol. Res. La Carbonerra, $2300 \mathrm{~m}$, Podocarpus forest, malaise trap, 28 June-3 July 1989 (S. and J. Peck); 1 male: above Merida, 2600 m, 3 August 1977, (Adams and Bernard); 1 male: Merida, La Carbonerra, Campo Elias, 30 June 1979 (R. W. Brooks, A. A. Grigarick, J. McLaughlin, R. O. Schuster).

Discussion. This species can be separated from osorioi males by the shape of the clypeus, slender mandible without a subbasal 
tooth, coarser punctation and paler marginal cell. The females are equally distinctive and can be immediately separated by the shape of the prothorax and basally indented procoxae, propodeum without a dorsomedial thorn, and tergum VI with a large ventrally projecting, triangular apicomedial tooth. Merithynnus pecki is named after Stuart Peck who collected the majority of specimens of this species, as well as many other thynnines.

\section{Merithynnus osorioi Kimsey, new species}

Holotype male: body length $16 \mathrm{~mm}$; clypeus produced into medial truncation, apicomedially slightly emarginate with acute lateral angles, apicolateral margin strongly concave (fig. 1); mandible slender with elongate apical tooth, large subapical tooth and large subbasal tooth on inner margin (fig. 1); frons with punctures nearly contiguous, deeply emarginate between frontal lobes; pronotum highly polished with tiny shallow punctures 2-4 PD apart; scutellum highly polished with punctures 2-5 PD apart; propodeum finely shagreened with faint sparse punctures; abdominal segments I-VI constricted basally and apically; genital capsule (fig. 13): gonostylus abruptly narrowed apically, ventral margin deeply indented subapically; aedeagus with shaft short and large ventral lobes before apical loop, fused medially. Body black with yellow markings as in pecki except not between ocelli, scutum and scutellum each with one medial spot, mesopleuron with three small spots, propodeum sublateral spots shorter, barely comma-shaped; tergum I without basal spots, and II-VI only with a small lateral spot; wings amber-tinted, with marginal cell more darkly stained.

Female: body length $10 \mathrm{~mm}$; mandible slender and edentate; frons polished with punctures 4-6 mm apart; subantennal distance to clypeal margin slightly shorter than malar space; thorax (fig. 10): pronotal disk subquadrate, convex medially, with no declivity before collar, anterolateral corners elevated with dorsal tuft of long erect setae, collar only slightly narrower than disk; propleura convex in profile; forecoxa not depressed anteriorly; thoracic dorsum appearing flat in profile; propodeum with long dorsal surface, sharply declivous to posterior face, juncture marked by sharp thornlike medial projection; parts of abdominal integument appearing minutely wrinkled otherwise highly polished; tergum VI pygidium coarsely and irregularly punctate, and covered by long erect 
dense setae apically 5-lobate, with shallow medial lobe (fig. 9); sternum VI apical plate forming a half circle, without dorsal emargination (fig. 9). Body dark reddish brown.

Holotype male: venezuela: Yaracuy, La Puerta, 11 November 1982, (J. M. Osorio). Paratypes, 1 female, same data as type (GAINESVILLE).

Discussion. As discussed under pecki the most distinctive male features of osorioi are the acute apical corners of the clypeus, absence of yellow bands on the terga, and the mandible with a subbasal tooth. Females can be readily distinguished by the convex and tufted pronotum, and dorsomedial thorn on the propodeum. Merithynnus osorioi is named after J. M. Osorio who collected the type series.

Mesothynnus Kimsey, new genus

(Figs. 4, 5, 8, 12)

Generotype: Thynnus gratiosus Smith 1859.

Diagnosis.

Male: body length $12-17 \mathrm{~mm}$; clypeus only slightly produced ventrally with depressed and polished medial triangle or rectangle, apical margin shallowly emarginate medially; mandible apically tridentate, or strongly dilated submedially; scutellum broadly convex; tergum VII apically rounded in dorsal view with lateral carinae; sternum VIII long and slender with sharp subapical angles and long medial prong (fig. 5); genital capsule (fig. 12): gonocoxa elongate and strongly convex dorsally and simple apically, gonostylus tapering apically, slightly angulate dorsally; cuspis with slender digitate lateral lobe; aedeagal shaft linear without lobes before apical loop. Body color black with yellow and orange maculation.

Female: body length $8-10 \mathrm{~mm}$; mandible slender and edentate; vertex posteriorly produced into two pointed lobes, notched between (fig. 4); pronotum sloping laterally, convex medially; propodeum with long dorsal surface sloping evenly to posterior surface; tergum I with one transverse carina; tergum II with three transverse carinae; tergum $\mathrm{V}$ with U-shaped apicomedial notch; sternum $\mathrm{V}$ with apical tuft of setae on either side of pygidium; tergum VI reduced and subconical, with posterior surface narrow, sharp-edged and scooplike (fig. 8); sternum VI cylindrical in 


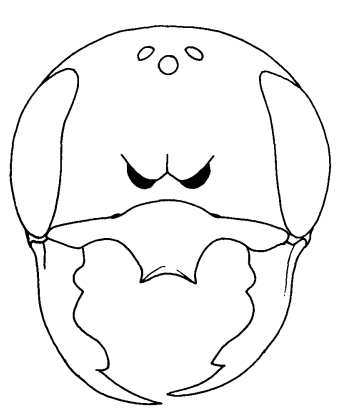

1. Merithynnus osorioi

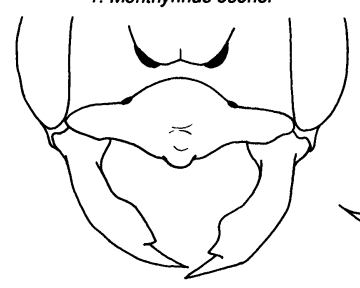

2. Atopothynnus unidens

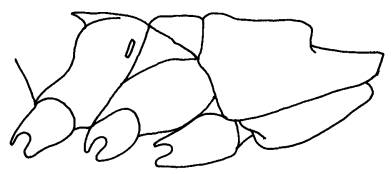

10. Merithynnus osorioi

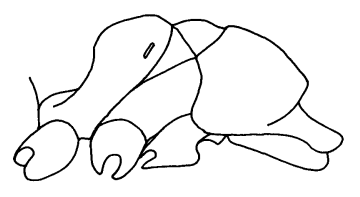

11. Merithynnus pecki

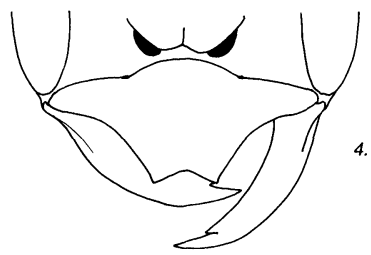

3. Merithynnus pecki
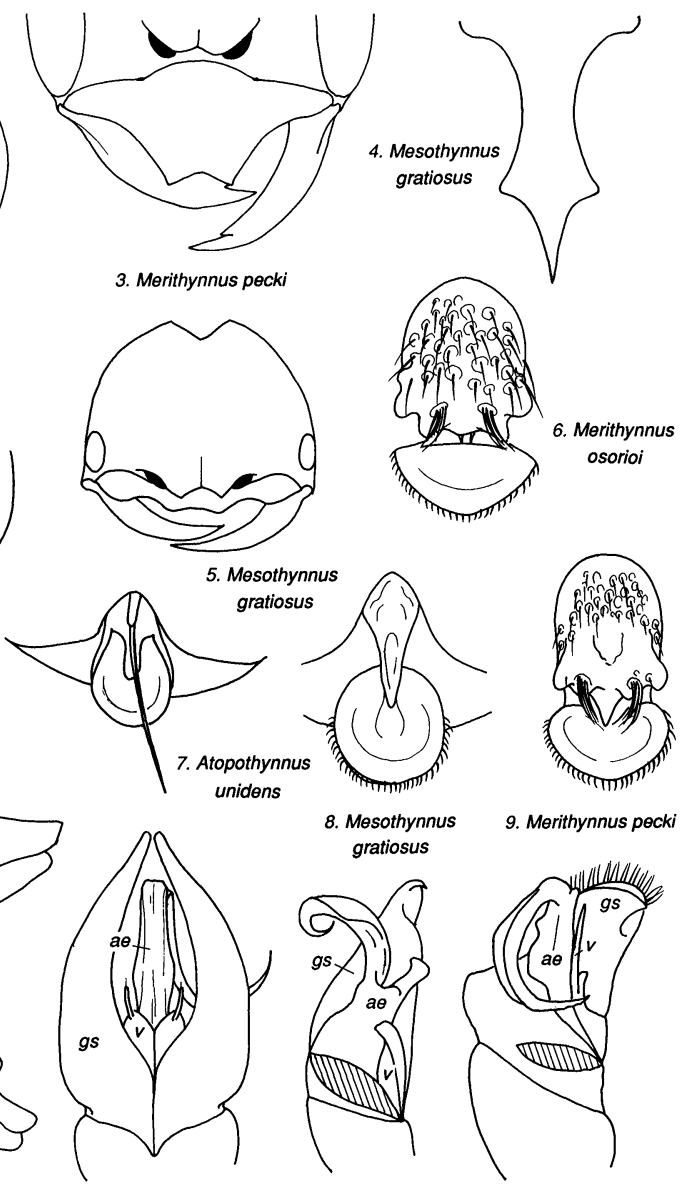

8. Mesothynnus

9. Merithynnus pecki gratiosus

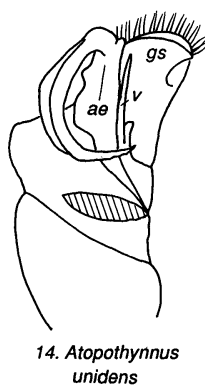

Figs 1-3. Front view of male face, antennae removed. Fig. 4. Front view of female face, antennae removed. Figs. 6-9. Posterior view of female apical abdominal tergum (dorsal) and sternum (ventral). Figs. 10-11. Lateral view of female thorax. Figs. $12-14$. Male genital capsule: $a e=$ aedeagus, $g s=$ gonostylus, $v=$ volsella. 
cross-section with horse hoof-like posterior plate (fig. 8).

Etymology: Meso-middle, referring to the clypeus; thynnus-a commonly used word root in the Thynninae (masculine).

Included species: Thynnus gratiosus Smith.

Distribution. This genus occurs in southern Brazil.

Discussion. Mesothynnus appears to be most closely related to Zeena Kimsey and Atopothynnus Kimsey, based on the shape of the cuspis, lack of a ventral lobe on the aedeagus and the subconical shortened female apical tergum. However, Mesothynnus can be immediately distinguished from these and other genera by the medially flattened and polished male clypeus, strongly triangular male sternum VIII, and obscure female pygidium which can be seen in the emargination of tergum $\mathrm{V}$.

\section{ACKNOWLEDGEMENTS}

This study was made possible by the individuals and institutions who loaned specimens for this study. This research was supported in part by NSF Research Grant No. RII-86-20062.

\section{Literature Cited}

SMITH, F.

1859 Catalog of the Hymenoptera in the British Museum 7: 10-69. TURNER, R. E.

1910a On the Thynnidae and Scoliidae collected in Paraguay. Zoologische Jahrbücher, Systematik 29: 179-227. 

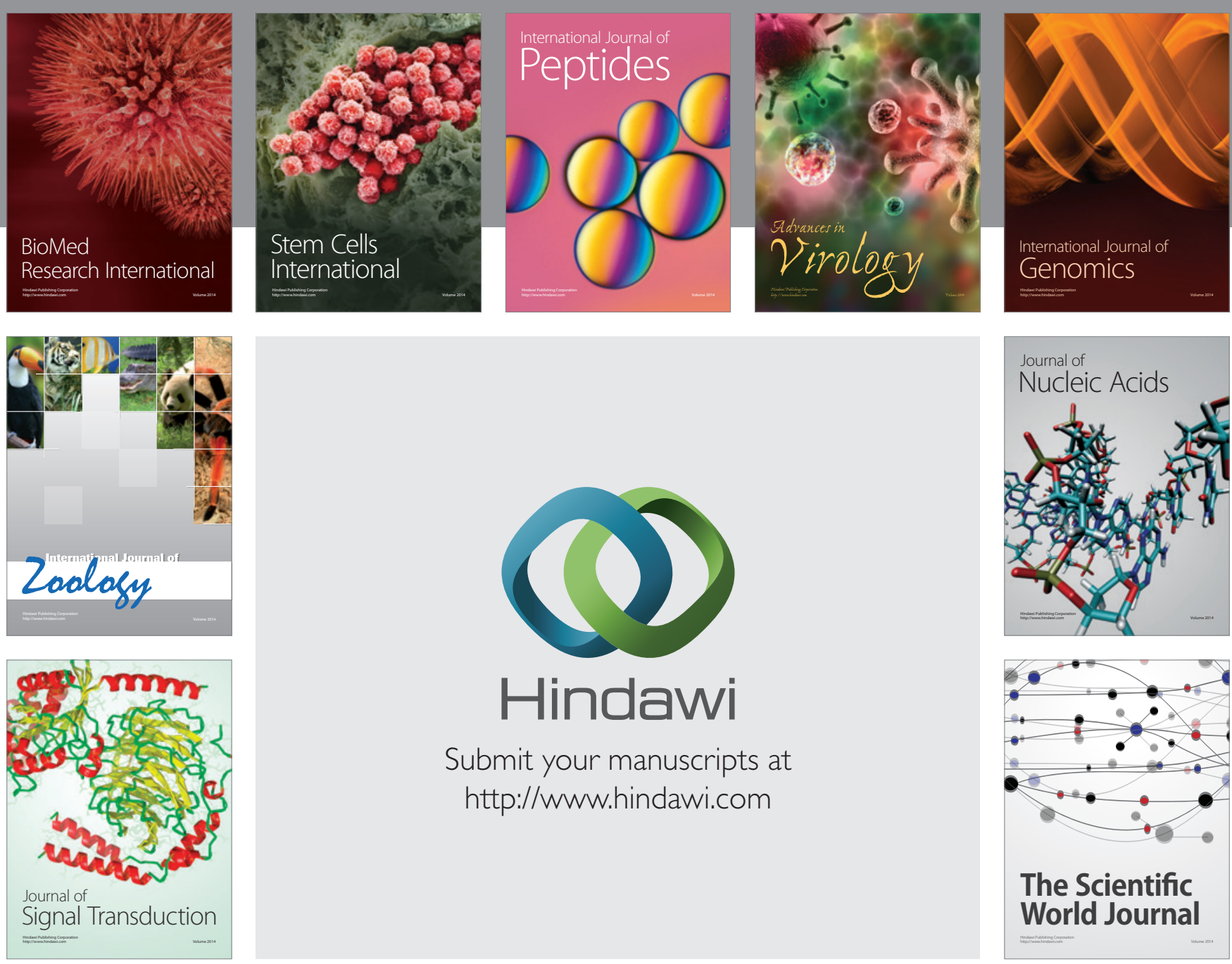

Submit your manuscripts at

http://www.hindawi.com
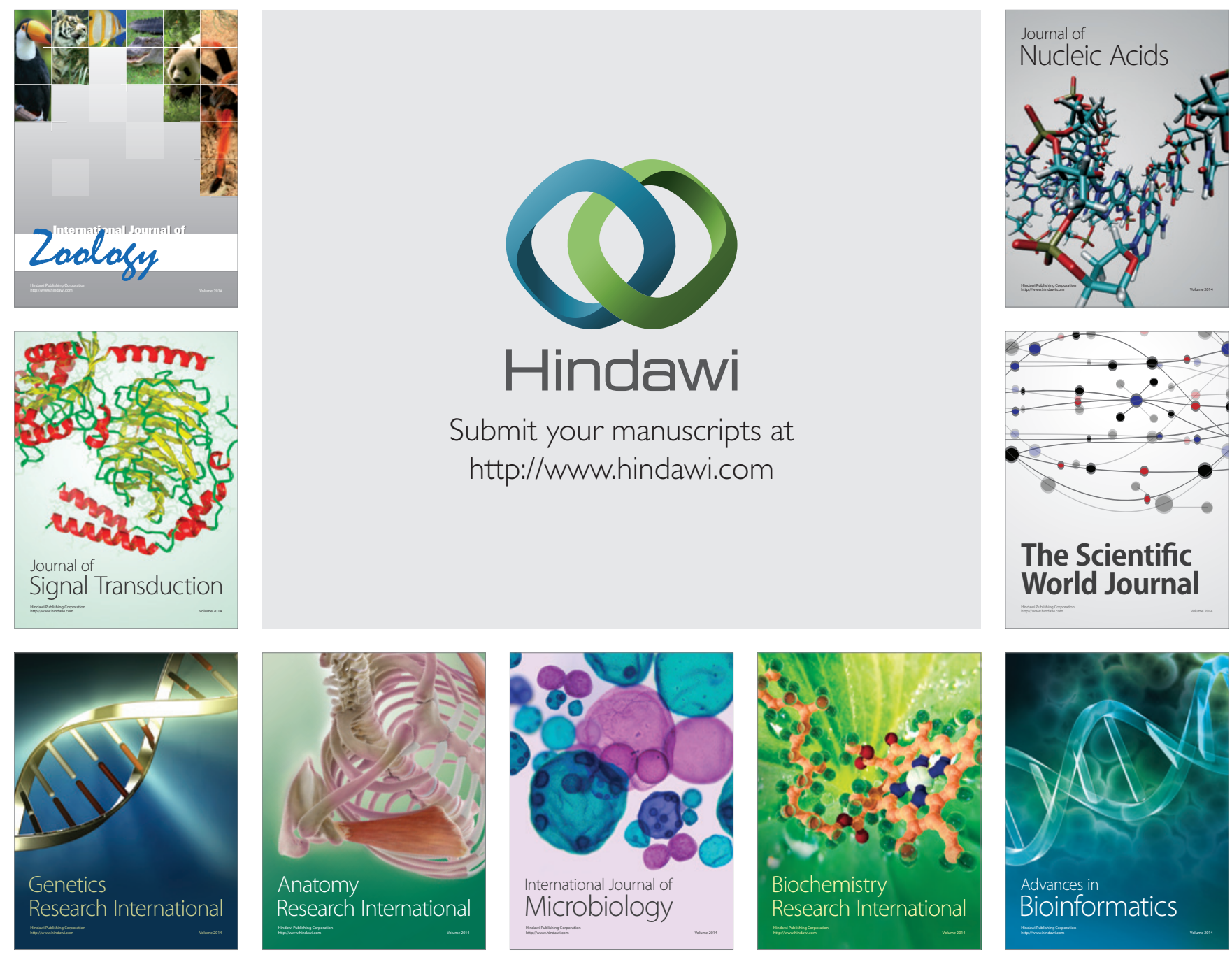

The Scientific World Journal
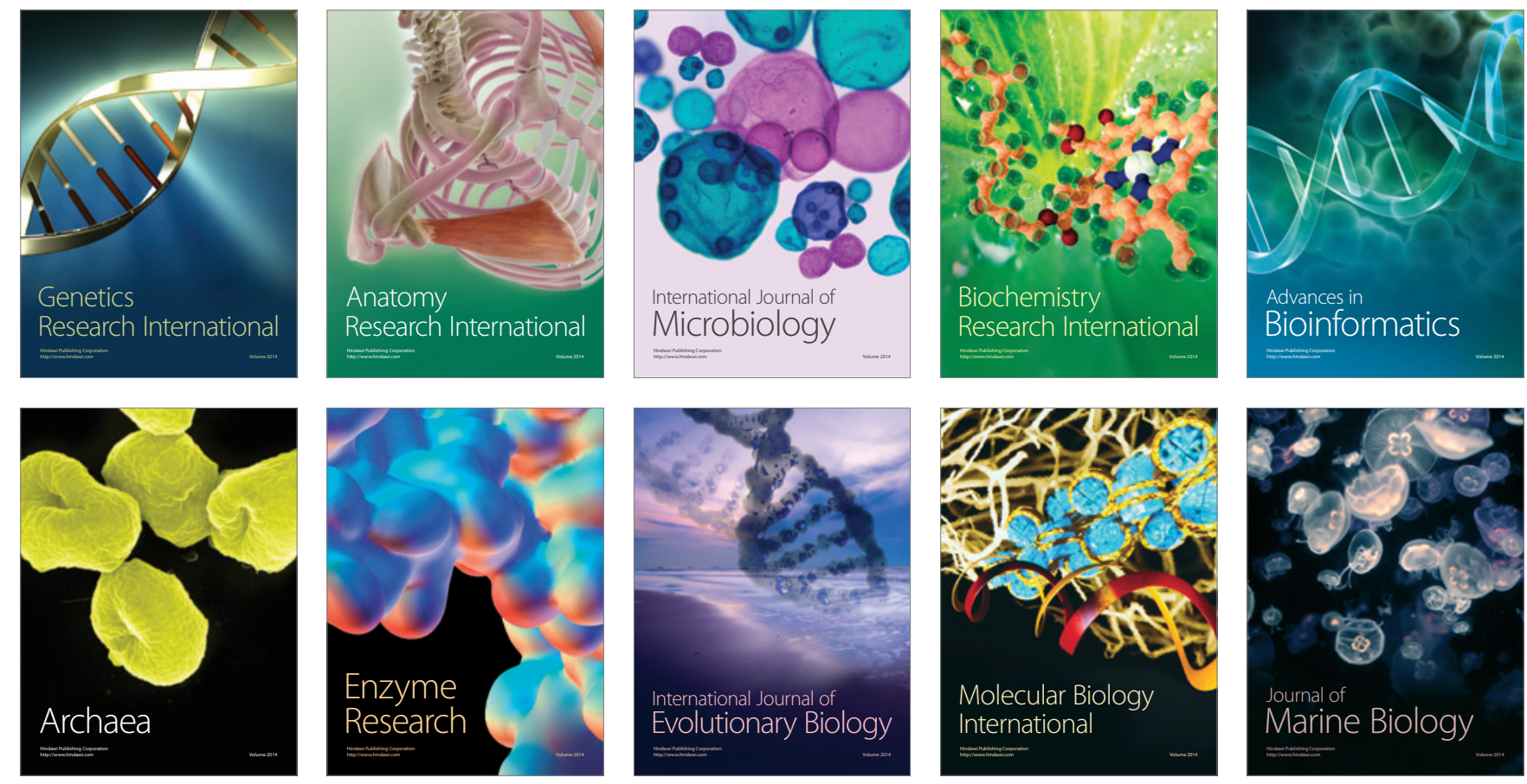